Review

\title{
The Complex Function of Hsp70 in Metastatic Cancer
}

\author{
Kata Juhasz, Anna-Maria Lipp, Benedikt Nimmervoll, Alois Sonnleitner, Jan Hesse, \\ Thomas Haselgruebler and Zsolt Balogi *
}

Center for Advanced Bioanalysis GmbH, Gruberstr. 40-42, A-4020 Linz, Austria

* Author to whom correspondence should be addressed; E-Mails: zsolt.balogi@cbl.at or zsolt.balogi@gmail.com; Tel.: +43-732-2468-7511; Fax: +43-732-2468-7530.

Received: 7 November 2013; in revised form: 5 December 2013 / Accepted: 11 December 2013 / Published: 20 December 2013

\begin{abstract}
Elevated expression of the inducible heat shock protein 70 (Hsp70) is known to correlate with poor prognosis in many cancers. Hsp70 confers survival advantage as well as resistance to chemotherapeutic agents, and promotes tumor cell invasion. At the same time, tumor-derived extracellular Hsp70 has been recognized as a "chaperokine", activating antitumor immunity. In this review we discuss localization dependent functions of Hsp70 in the context of invasive cancer. Understanding the molecular principles of metastasis formation steps, as well as interactions of the tumor cells with the microenvironment and the immune system is essential for fighting metastatic cancer. Although Hsp70 has been implicated in different steps of the metastatic process, the exact mechanisms of its action remain to be explored. Known and potential functions of Hsp70 in controlling or modulating of invasion and metastasis are discussed.
\end{abstract}

Keywords: Hsp70; metastasis; invasion; trafficking; lysosome

\begin{abstract}
Abbreviations
AIF: apoptosis-inducing factor; Apaf-1: apoptotic protease activating factor-1; APCs: antigen-presenting cells; Ask-1: apoptosis signal-regulated kinase 1; ASM: acid sphingomyelinase; BMDCs: bone marrow-derived cells; BMP: bis(monoacylglycero)-phosphate; CHIP: carboxyl-terminus of Hsp70 interacting protein; DCs: dendritic cells; ECM: extracellular matrix; EGFR: epidermal growth factor receptor; EMT: epithelial-mesenchymal transition; ERK: extracellular signal-regulated kinase; FAK: focal adhesion kinase; HMGB1: high mobility group protein B1; Hop: Hsp70/Hsp90
\end{abstract}


organizing protein; HSF: heat shock factor; Hsp70: heat shock protein 70; HspBP1: Hsp70 binding protein 1; JNK: c-Jun $N$-terminal kinase; LAMP-1: lysosomal-associated membrane protein-1 MAPK: mitogen-activated protein kinase; MDSC: myeloid-derived suppressor cells; MMPs: matrix metalloproteases; NF-кB: nuclear factor kappa-light-chain-enhancer of activated B cells; NK: natural killer; NO: nitric oxide; PMA: phorbol 12-myristate 13-acetate; pMHC: peptide-loaded major histocompatibility complex; ROS: reactive oxygen species; TCR: T cell receptor; TGF-beta: transforming growth factor-beta; tTG: tissue transglutaminase; TLR: Toll-like receptor; TNF: tumor necrosis factor; Wasf3: Wiskott-Aldrich syndrome protein family member 3.

\section{Introduction}

The stress-inducible heat shock protein 70 (Hsp70) also known as HSPA1A, Hsp70-1, Hsp72 or HspA1 [1], is produced at low or undetectable levels in unstressed, healthy cells. Upon a variety of stresses its expression is rapidly induced through mitogen-activated protein kinase/extracellular signal-regulated kinase (MAPK/ERK) and stress-activated protein kinase (SAPK) signaling cascades activating heat shock factors (HSFs) [2-4]. Hsp70 restores the balance of cell proteome by normalizing the concentration of unfolded and denatured proteins. Being a molecular chaperone, Hsp70 is an important part of cellular networks, including transcriptional, signaling, membrane and organelle networks [5].

The tumor microenvironment, where cells are subjected to free radicals, acidosis, hypoxia and nutrient deprivation, as well as high levels of mutant proteins, causes stressful conditions challenging cancer cells [6]. Accordingly, constitutive high levels of Hsp70 are frequently observed in various cancer cells [7,8], where Hsp70 enhances cell growth, suppresses senescence, and confers resistance to stress-induced apoptosis. Origin of elevated Hsp70 levels in cancer cells is thought to result from the need for antistress proteins. It has been hypothesized that elevated Hsp70 level in cancer cells is a consequence of altered HSF1 transcriptional activity [9-11], although Hsp70 may be also expressed regardless of HSF1 [12]. Interestingly, inhibition of Hsp70 in tumor cells is often lethal [13] and silencing of Hsp70 kills several types of cancer cells in culture as well as in tumor xenografts in mice [13-15]. Other rodent cancer models pointed to the tumorigenic potential of Hsp70 [16-19]. Although a large body of evidence supports the importance of Hsp70 in oncogenesis, the exact mechanisms remain elusive.

Expression level of Hsp70 is a diagnostic measure in several cancers, as Hsp70 overexpression can be correlated with increased cancer cell proliferation [20], clinical stage [21,22] or increased grade and shorter overall survival [23]. Extensive research in the last decades potentiated Hsp70 as a marker molecule in cancer treatment. Hsp70 is a good tumor marker to identify patients with early-stage prostate cancer [24] and hepatocellular carcinoma [25]. High expression levels of Hsp70 correlate with poor prognosis in acute myeloid leukemia, in cancers of the breast, endometrium [8,26-28] and rectum [29]. Furthermore, Hsp70 expression might be of use to assess the progression of esophageal squamous cell carcinoma [30,31]. However, elevated Hsp70 level is not a general marker of poor prognosis, as it has no prognostic relevance in gastric cancer [29,32], or even indicates good prognosis in renal and esophageal cancer [7,33]. Interestingly, Hsp70 levels correlate with malignancy in osteosarcoma and renal cell tumors, whereas associate with improved prognosis [7,34]. Accordingly, association of Hsp70 expression and clinical outcome largely depends on the cancer type and stress 
conditions. Cancer cell specific surface localization or release of Hsp70 exhibits additional activities of this stress protein [35-39]. Hsp70 exerts a dual role in cancer, promoting survival and dissemination of tumor cells, and at the same time contributing to antitumor immunity.

Metastasis is a result of a series of highly orchestrated processes, including epithelial-mesenchymal transition (EMT), alteration of cell adhesion and motility, inducing neoangiogenesis, invasion into tissue, intravasation, and surviving in the blood or lymphatic vessels. Besides the extensively studied Hsp90, Hsp70 family members have been implicated in metastasis formation as well [40-42]. Elevated Hsp70 expression has been found to correlate with lymph node metastases and decreased survival in breast cancer models [43]. It has been hypothesized that membrane Hsp70, like membrane Hsp90 [44], might support the spread of distant metastasis. The fact that Hsp70 expression can influence metastasis development and drug resistance further highlights the need for understanding its role in cancer progress [45-47]. This review focuses on our current understanding of the pleiotropic properties of Hsp70 in metastatic cancer cells.

\section{Hsp70 Supports Metastatic Cancer Cell Growth through Chaperone and Antiapoptotic Functions}

Elevated Hsp70 expression, frequently associated with transformed phenotype, may provide a selection advantage to cancer cells, whereas depletion of Hsp70 promotes G2/M cell cycle arrest [47] and tumor regression [19]. It has been assumed that elevated Hsp70 expression relates to cell growth in epithelial carcinoma cell lines [48,49]. Hsp70 as a molecular chaperone has long been in the focus of cancer research that revealed a number of client proteins interacting with Hsp70 during cell growth (reviewed in [50]). Among several hypotheses on the role of Hsp70 in human malignancies it has been suggested that high levels of inducible Hsp70 in tumor cells may be required for stabilizing mutant oncogene products during tumor growth [51,52]. Detailed molecular mechanisms of chaperone activity of Hsp70 enhancing tumor cell growth have been reviewed elsewhere [53].

Because of shear stress through vasculature transit and lacking of survival signals from adhesive sites, metastatic steps are particularly stressful for disseminating cells, making metastasis an ineffective process $[54,55]$. Therefore, survival pathways must be enhanced in order for selection of aggressive tumor cells. Metastatic cells likely benefit from Hsp70 chaperone functions supporting cellular growth. Nevertheless, the beneficial effect of Hsp70 on cell growth widely reported for primary cancer cells remains largely unexplored for metastatic cells. In fact, it is mainly coupled to other aspects of metastasis, such as cytoskeleton-dependent signaling. Indeed, proliferation of human colonic carcinoma cells correlated with co-expression of Hsp70 and CD44 [56], a surface molecule implicated in tumor cell survival during micrometastasis formation [57].

Besides chaperoning cancer cell growth, Hsp70 has been shown to inhibit cancer cell death induced by different stimuli such as oxidative stress, inflammatory cytokines, anticancer drugs or irradiation [58-65]. Consistently with its known substrate promiscuity, Hsp70 interacts with multiple partners in the signaling cascades of apoptosis and senescence. Hsp70 has been shown to directly bind to and inhibit apoptosis signal-regulated kinase 1 (Ask1), p38 MAPK and c-Jun N terminal kinase (JNK), thereby blocking stress-induced cell death [66-69]. Hsp70 modulates ERK signaling upon heat stress and hyperosmolarity-induced apoptosis [70-72]. In tumor cells, there has been shown a suppressive role of Hsp70 in senescence through controlling p53 and ERK activity [45,73]. Inducible 
Hsp70 plays a negative regulatory role in the mitochondrial apoptotic pathway at several steps. Hsp70 directly binds to apoptosis protease-activating factor-1 (Apaf-1), thereby preventing the recruitment of procaspase-9 to the apoptosome [74]. Hsp70 interferes also with caspase-independent apoptotic pathways, interacting with apoptosis-inducing factor (AIF), in turn inhibiting AIF-induced chromatin condensation [75]. Additionally, Hsp70 has been shown to accumulate in the lysosomes of many tumor cell types, preventing lysosomal membrane permeabilization-induced cell death $[65,76]$. Detailed mechanisms of the involvement of $\mathrm{Hsp} 70$ in apoptotic pathways are reviewed elsewhere [9,53,77].

Avoiding apoptosis is crucial for tumor cells during the metastatic process. Alteration in cell adhesion to extracellular matrix (ECM) proteins is one of the earliest steps in cancer metastasis [78]. Involvement of signaling molecules such as focal adhesion kinase (FAK), Met and Akt have been shown to play a role in anoikis and amorphosis, apoptotic processes that normally occur to cells losing contact with ECM [79]. Activity of these molecules has been reported to be influenced by Hsp70 [80-82], raising a possible regulatory role of Hsp70 in these processes typically inhibited in metastatic cancer cells. It has also been suggested that Hsp70 could directly protect members of cytoskeletal-based cell survival pathways [14]. Indeed, interaction between FAK and Hsp70 prevents FAK degradation by activated caspase-3 and may represent a novel mechanism for cytoprotection [82]. It has been recently shown that matrix metalloproteases (MMPs), in addition to being active during invasion, are involved in regulating apoptosis $[83,84]$. MMPs may interfere with cell death by cleaving death receptors, as well [85]. Since Hsp70 expression is known to affect MMP secretion and activity in cancer [86,87], Hsp70 levels may indirectly determine the fate of a metastatic cancer cell. Further studies using appropriate models would be still necessary to dissect the role of Hsp70 in conferring a survival advantage on cancer cells at different steps of metastasis.

\section{Hsp70 Supports Metastasis through Promoting Invasion Steps}

Upon tumor progression and antitumor treatments cancer cells are exposed to various forms of stress such as proteasome inhibition, hypoxia or heat stress, which have been reported to induce metastatic steps including EMT, cell migration and invasion [88,89]. Hsp70 overexpression correlates with a more aggressive phenotype in several cancer types. Elevated expression of Hsp70 has been found to correlate with lymph node metastasis in breast cancer cells as mentioned above [43] and with vascular invasion in gastric cancers [90]. In cervical and bladder cancer cells shRNA knockdown of Hsp70 has been shown to suppress invasion and migration [91]. In accordance, Rohde et al. suggested a role for Hsp70 in cancer cell adhesion, as depletion of Hsp70 resulted in cell detachment [47].

During invasion tumor cells need to penetrate surrounding tissue. This process requires enhanced cell motility and reduced adhesion, acquired by EMT. Notably, the carboxyl-terminus of Hsp70 Interacting Protein (CHIP) downregulates Met, one of the key receptors triggering EMT [92] via a switch from Hsp70 chaperone activity to proteosomal targeting [81]. Essential role of Hsp70 in transforming growth factor-beta (TGF-beta) induced EMT has been revealed, where Hsp70 blocks TGF-beta signaling by impeding Smad2 phosphorylation [93]. As EMT is thought to be a prerequisite for the invasive behavior of cancer cells, further studies may help targeting Hsp70 to prevent metastasis. Although Hsp70 is known to influence the activity of molecules involved in cell 
motility $[41,82,94]$, little is known about the role of Hsp70 in cancer cell migration. Knockdown of Hop caused a decrease in the level of RhoC GTPase, and significantly inhibited pseudopodia formation in cancer cell lines [95]. Activity of Hsp70/Hsc70 has been found essential for cell motility revealed by experiments inhibiting their ATPase activity in EGF stimulated cells [96]. In the same publication tissue transglutaminase was identified to translocate to the leading edge of the cell depending on active Hsp70. Remarkably, at the same site further interaction partners of Hsp70 are present that are involved in cell motility. Hsp70 is known to stabilize FAK [82] as well as Wiskott-Aldrich syndrome protein family member 3 (Wasf3) [91], a molecule involved in lamellopodia formation and metastasis [97-99]. A potential linker represents the Hsp70 regulator BAG3. The SH3 binding motifs of BAG3 could target Hsp70 protein complexes to signaling complexes at the leading edge of the cell. Indeed, reduced motility of BAG3-deficient mouse endothelial fibroblasts and BAG3 depleted cancer cell lines was observed [100]. In addition, BAG3 provides a potential link to the modulation of the extracellular matrix, another key step in invasion. Immunoprecipition indicated BAG3 as an interaction partner of MMP-2 [101].

Besides the rather indirect link of Hsp70 to MMPs via BAG3, MMP-2 is directly activated by Hsp90 [102] in an extracellular chaperonin complex with Hsp70/Hsp90 organizing protein (Hop) and Hsp70 [103]. Knockdown of Hop reduced the expression of MMP-2 and other proteins implicated in invasion and metastasis [103]. Whether MMP levels correlate with negative outcome and tumor aggressiveness is still unclear [104]. Remarkably, in glioblastoma xenografts CD44, a receptor involved in EMT and migration [105] is activated by MMP-9 [106], which in turn, is released in the presence of extracellular Hsp70 [87]. Furthermore, the presence of extracellular Hsp70 can trigger an inflammatory microenvironment and angiogenesis, which are hallmarks of cancer development as discussed later in this review. Therefore, Hsp70 has multiple activities which potentially contribute to invasion and metastasis (Figure 1).

\section{Impact of Hsp70 Trafficking on Metastasis}

Increased level of Hsp70 in patients' blood samples and in the extracellular milieu appears to be a general feature of cancers [107]. Tumor-derived extracellular Hsp70 can be attributed to necrotic cell death, where the large amount of mainly intracellular chaperone signals as danger for the immune system. In addition, active release mechanisms have been reported as source of extracellular Hsp70, depending on cell type and conditions. The exact mechanism of tumor-specific surface targeting and release of Hsp70, as well as mechanistic details of its intracellular trafficking still remain to be explored.

Hsp70, a leaderless chaperone has been proposed to cross the membrane through its ability to bind to phosphatidylserine [108] and formation of pores shown in artificial lipid membranes [109]. The authors suggested a mechanism of surface expression and release independent of vesicular trafficking. Association of Hsp70 with lipid rafts has also been reported [110], which was consistent with the idea of some involvement of membrane domains in active release of Hsp70 [110-112]. The endolysosomal system has been implicated in Hsp70 trafficking in various cell types [37,65,110,112-114]. Exosomal transport of Hsp70 has been shown for tumor cells in vitro and in vivo, which could be facilitated by drugs or heat shock [115-117]. In addition, in human peripheral blood mononuclear cells, "exonemes" have been identified to secrete Hsp70 [113]. As an alternative mechanism, Hsp70 has been shown to 
be actively released via secretory lysosomes in a soluble form [114,118]. Interestingly, excess of Hsp70 in a melanoma model was shown to facilitate lysosomal routing, surface expression and release of Hsp70 [118]. Noteworthy, internalized surface Hsp70 has been demonstrated to be released in both membrane-bound and soluble forms [37,118]. Removal of internalized surface Hsp70 that trafficked through the endosomal/lysosomal sytem has been suggested as potentially highly immunogenic.

Figure 1. Potential metastasis promoting activities of Hsp70. Elevated expression of Hsp70 in tumor cells has beneficial effect on metastatic cell growth through cytoskeleton-dependent signaling. Hsp70 interacts with multiple partners in the mitochondrial and lysosomal signaling cascades of apoptosis, providing selection advantage for aggressive tumor cells by antiapoptotic activities. Hsp70 enhances motility and invasion through interactions with proteins involved in EMT, lamellipodia formation and ECM degradation. Tumor-derived Hsp70 promotes inflammatory conditions in the tumor microenvironment, thereby enhancing invasion and angiogenesis, in turn metastasis.

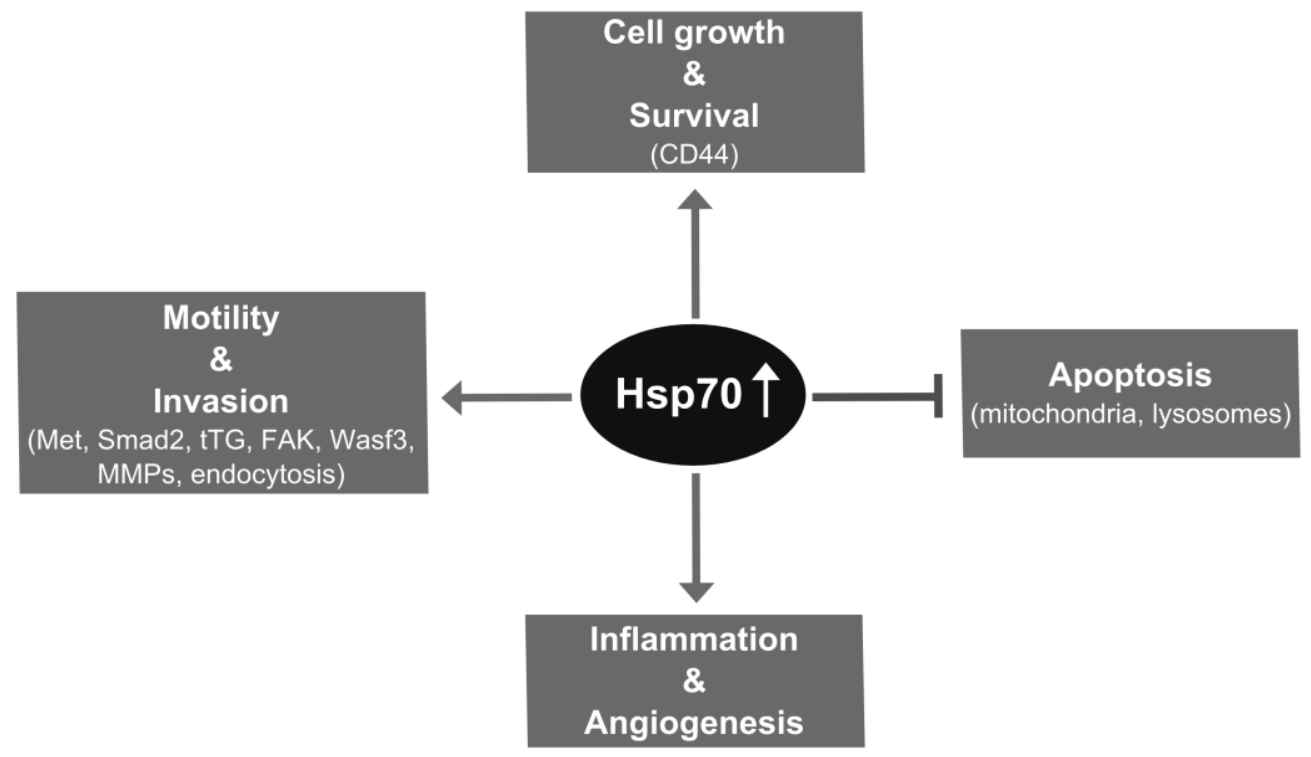

In fact, a subfraction of Hsp70 has been found to accumulate in lysosomes of many cancer cell types. Hsp70 has been also demonstrated to bind to the limiting membrane of lysosomes at the lumenal side, through pH-dependent high-affinity binding to bis(monoacylglycero)phosphate (BMP) [119]. Hsp70 has been suggested to be targeted to lysosomes by autophagy [120,121] or by endocytosis from the plasma membrane [122], unexplored proposed mechanisms of Hsp70 membrane crossing. Interestingly, Hsp70 appears to inhibit a unique pathway of cell death in tumor cells, which involves lysosomal membrane permeabilization and activation of caspase-3 [65,123]. Hsp70 localized to membranes of the endosomal/lysosomal compartment counteracts lysosomal membrane permeablization and release of cathepsins, in turn preventing apoptosis $[65,80]$.

In addition to protecting cells from apoptosis through lysosomal membrane stabilization [65], Hsp70 sustains the activity of acid sphingomyelinase (ASM). Hsp70 and ASM have been proposed to influence dynamics of the vesicular system, including endosomes, multivesicular bodies, autophagosomes and lysosomes. Moreover, it has been hypothesized that Hsp70 may regulate trafficking of these organelles [119]. Proper trafficking of lysosomes may be crucial for tumor growth 
and metastasis formation, as enhanced release of lysosomal content into the extracellular space can facilitate matrix degradation, in turn invasion [124]. Indeed, trafficking of lysosomes appears to be altered in cancer cells. As compared to healthy cells, cancer cells have more lysosomes near the cell surface, which more frequently fuse with the plasma membrane and secrete their content such as cathepsins capable of promoting invasion and angiogenesis $[125,126]$. In support of the idea that Hsp70 may influence lysosomal trafficking, we observed Hsp70 to accumulate in the lysosomes of Hsp70 overexpressing melanoma cells, which correlated with an increased rate of lysosomal trafficking measured as lysosomal-associated membrane protein-1 (LAMP-1) surface exposure [127]. Moreover, we also visualized Hsp70 being released from lysosomes that fuse with the plasma membrane upon different stress triggers (Figure 2).

Figure 2. Lysosomes secreting Hsp70 from melanoma cells. Stable clones of mouse B16 cells were generated and induced to express Hsp70-E3. Hsp70-E3 exposed at the cell surface was labelled with the complement peptide K4 conjugated to AlexaFluor488 [128]. Prior to imaging, cells were transiently transfected with LAMP-1-mKate to label the late endosomal/lysosomal membrane. Release of Hsp70 via lysosomes fusing with the cellular membrane was visualized by total internal reflection fluorescence (TIRF) microscopy upon addition of $1.4 \mu \mathrm{M}$ ionomycin (scale bar $=10 \mu \mathrm{m}$ ). Note that release of the Hsp70-E3-K4 adduct could also be triggered by heat stress $[118,127]$ Hsp70 and LAMP-1 are displayed in green and red, respectively. Arrowheads indicate sites of vesicular fusion. Note shedding the soluble lysosomal content (Hsp70) followed by spreading of the vesicular membrane marker (LAMP-1) in the plasma membrane. See also movie as supplementary information.
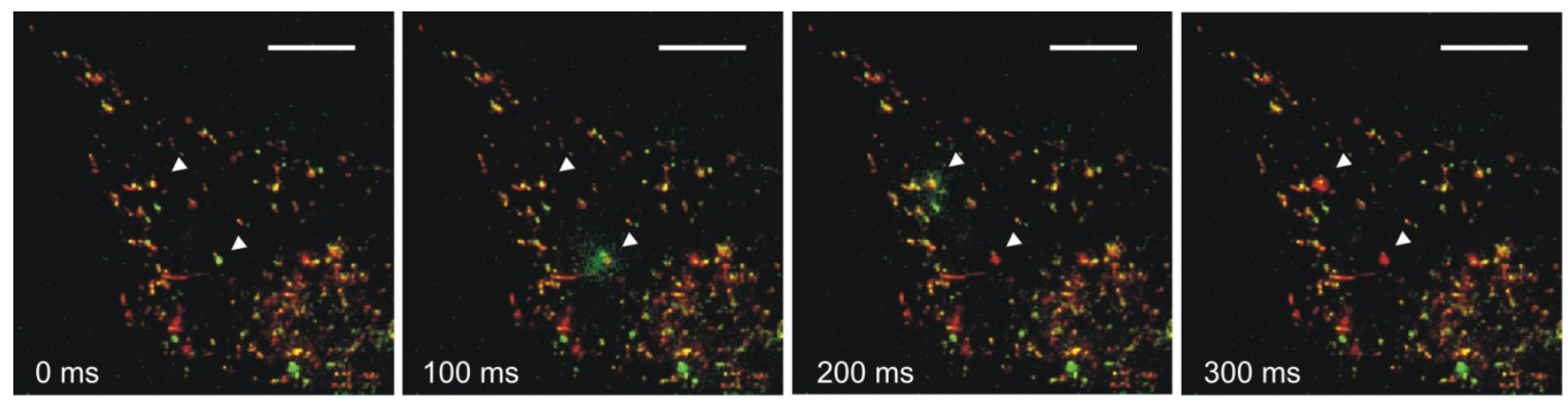

This potentiates that Hsp70 may indirectly or directly influence secretion of lysosomal enzymes digesting the extracellular matrix, hence facilitating tumor cell invasion. Nevertheless, such potential role, and in particular mechanism of Hsp70 action in regulation of lysosome trafficking remains to be explored. This task would require appropriate tools enabling to monitor intracellular trafficking during invasion. Spatiotemporal visualization of cancer cells during invasion at the molecular level sets technically challenging requirements. Cells need to be monitored in real time, in multiple focal planes with high temporal and spatial resolution in tissue or extracellular matrix material. Future technical developments, therefore, may help to get a deeper insight into localization dependent function of Hsp70 in a complex and dynamic environment.

Hsp70 has been implicated in endosomal trafficking of cancer cells. Elevated expression of Hsp70 gave rise to trafficking of CD44v6 to the plasma membrane [129] or clathrin dependent endocytosis measured by transferrin uptake in human hepatoblastoma cells [122]. Enhanced endocytosis of 
nutrients may also serve as a pro-cancer activity of Hsp70 expression [129]. Hsp70 is capable of supporting or counteracting cancer progression, dependent on the fate of an individual tumor cell. Notably, exposure of the immune stimulatory Hsp70 on the tumor cell surface has been considered as an "unfortunate consequence" of lysosomal release mechanisms, which may explain why tumor cells with surface Hsp70 positivity and Hsp70 release are not selected during carcinogenesis and metastasis [80]. Therefore, although avoiding elevated extracellular Hsp70 may be a favorable approach in anticancer therapies, surface Hsp70 positivity of survival cancer cells stressed by therapy may account for a therapeutic advantage if an enhanced immune response against the resistant populations is achieved. The importance of surface Hsp70 expression and signaling as well as coordinated vesicle trafficking in invasion and metastasis have been only recently recognized [107]. Further studies on the influence of Hsp70 on vesicular trafficking may contribute to control cancer cell invasion.

\section{Extracellular Functions of Hsp70}

Cancer-specific surface expression and release of Hsp70 further increase the already broad spectra of Hsp70 activities. Depending on the release mechanism, extracellular Hsp70 exists in a free soluble form, complexed to antigenic peptides, or in exosomes [37,110,113,130]. It seems likely that different forms of extracellular Hsp70 mediate distinct functions, mainly through interactions with different types of target cells and subsequent signaling. The observed signaling capacity of extracellular Hsp70 can be ascribed to its interaction with a number of transmembrane immune receptors differentially expressed on cells in the tumor microenvironment, including immune cells, tumor cells, endothelial and epithelial cells (Figure 3).

Extracellular Hsp70 complexed to tumor peptides has been shown to interact with scavenger receptors on antigen-presenting cells, like CD91, SREC-1, and LOX-1 [131-134]. This is followed by peptide-Hsp70 complex uptake via receptor-mediated endocytosis, leading to antigen cross-presentation on MHC I molecules [135-138] and an adaptive tumor-specific immune response mediated by CD $8^{+}$ cytotoxic T cells [136,138-140]. Hsp70 of tumor-derived exosomes has been reported to activate natural killer (NK) cells [37]. In accordance, treatment with full-length Hsp70 or the 14-mer peptide TKD, being identified as the fragment of Hsp70 exposed on the tumor cell surface [141], triggers expression of activating receptors, such as CD94, and initiates proliferation, cytolytic and migratory capacity of resting NK cells [37,142-144]. Similar effects upon Hsp70 exposure have been described for $\mathrm{CD}^{+} \mathrm{T}$ helper cells, as well [145]. Noteworthy, enhanced immune functions of exosomes appear to be associated with Hsp70 expressed in the exosomal membrane [146].

Peptide-free extracellular Hsp70 has been reported to act on the innate immune system, predominantly via activation of Toll-like receptor (TLR) $2 / 4$ signaling $[39,147,148]$. It has been shown that exposure to extracellular Hsp70 results in the release of proinflammatory cytokines and nitric oxide (NO) from macrophages [39,130,149-151], as well as upregulation of costimulatory molecules, chemoattraction and activation of dendritic cells (DCs) [149,152-154]. In this way, extracellular Hsp70 acts as a danger signal and provides an inflammatory tumor microenvironment. However, since Hsp70 can bind LPS, which also triggers TLR4 signaling, these data have to be interpreted carefully regarding possible effects mediated by LPS contamination rather than Hsp70 itself, as reviewed elsewhere [155-159]. 
Figure 3. Versatile functions of extracellular Hsp70. Extracellular Hsp70 is able to interact with receptors expressed on cells of the tumor microenvironment. Hsp70 complexed to tumor-derived peptide binds to scavenger receptors on antigen presenting cells (APC), and is internalized and cross-presented to $\mathrm{CD}^{+} \mathrm{T}$ cells, thereby an adaptive tumor-specific immune response is initiated. Stimulation of NK cells by Hsp70 leads to increased cytotoxic activity against Hsp70-positive tumor cells. Hsp70 has an immunosuppressive role via recruitment and activation of regulatory $\mathrm{T}$ cells (Treg) and myeloid-derived suppressor cells (MDSC), leading to the downregulation of T cell responses. Hsp70 acts as a danger signal via binding to Toll-like receptors (TLRs) on mononuclear cells, leading to secretion of pro-inflammatory cytokines and nitric oxide (NO), in turn providing an inflammatory environment that contributes to metastasis formation. Hsp70 promotes tumor invasion and angiogenesis through activation of MMP-2 and production of ROS by neutrophils, respectively. Binding of Hsp70 to epithelial cells results in secretion of pro-inflammatory cytokines, activating an amplification loop.

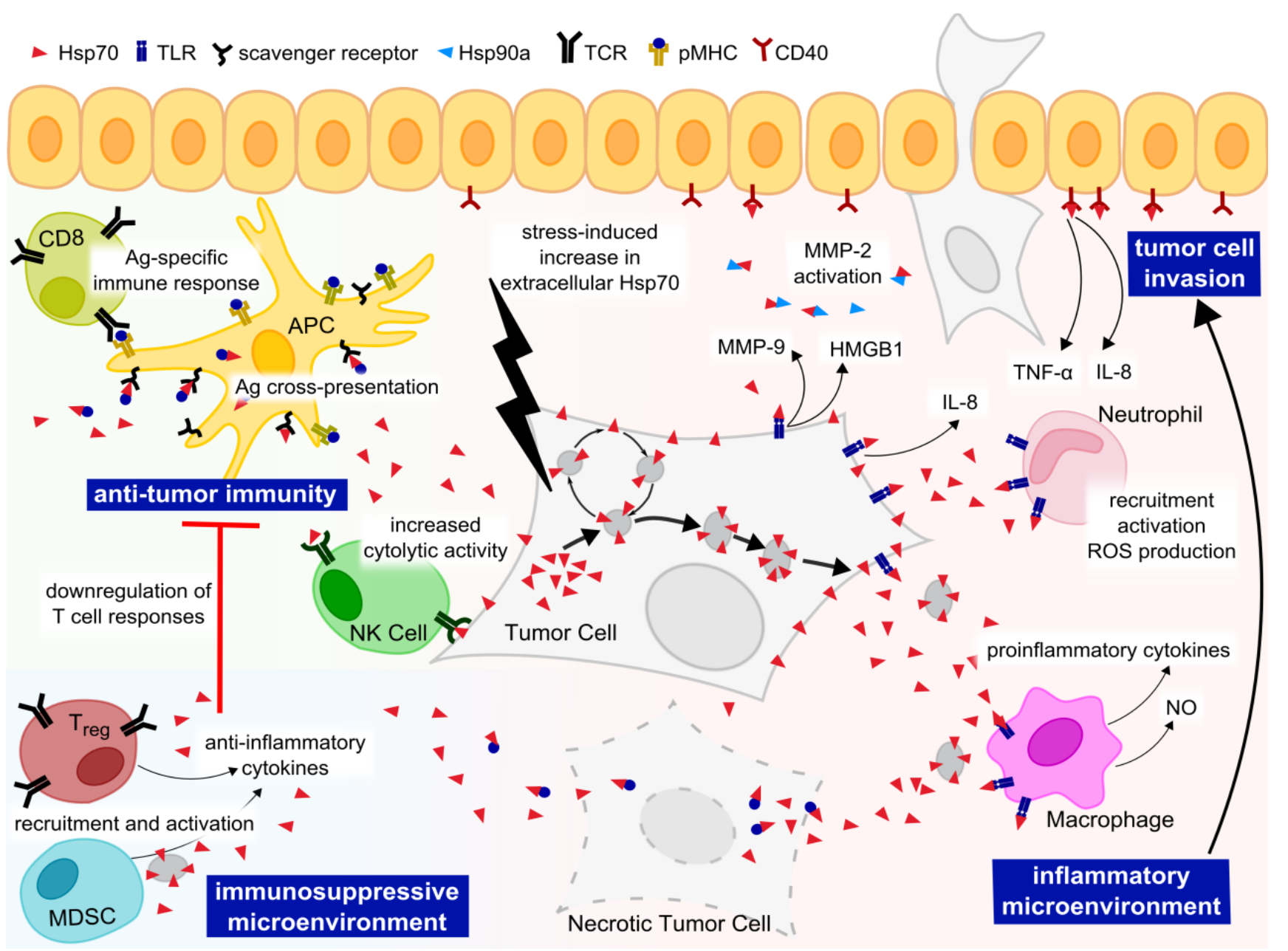

Cancer-related inflammation plays a pivotal role in cancer development. Infiltrating immune cells might exert antitumor activity at early stages, but support tumor growth and metastasis at a chronic stage (reviewed in [160]), suggesting a role for extracellular Hsp70 in tumor progression. Additionally, extracellular Hsp70 could contribute to tumor progression via promoting an immunosuppressive tumor microenvironment, as well. It has been shown that free or exosome-bound Hsp70 can recruit and 
activate Foxp $3^{+}$regulatory T cells [161] or myeloid-derived suppressor cells, respectively [162]. This immunosuppressive tumor microenvironment eventually results in production of anti-inflammatory cytokines and dampened $\mathrm{T}$ cell responses through suppression of $\mathrm{T}$ cell proliferation and induction of tolerogenic DCs [161,163-165]. Recent data in mice and human models showed that tumor-derived exosomes exposing Hsp70 on the surface impair anti-tumor immunity [162].

Besides acting on immune cells, extracellular Hsp70 can trigger signaling in tumor cells in an autocrine or paracrine fashion via binding to TLR2/4, thereby playing a role in invasion and angiogenesis. It has been shown that extracellular Hsp70 released from heat-stressed A431 squamous carcinoma cells triggers autocrine epidermal growth factor receptor (EGFR) and MAPK signaling via TLR2/4 [166]. EGFR signaling is involved in MMP activation [167] and secretion of interleukin (IL)-8 [168], and has often been associated with tumor invasion and metastasis [169]. In another study binding of extracellular Hsp70 to TLR2/4 on H22 hepatocarcinoma cells triggered nuclear factor kappa-light-chain-enhancer of activated B cells (NF-kB) pathways, resulting in proliferation and resistance to apoptosis [170]. Tumor progression mediated by extracellular Hsp70 was further enhanced via a positive feedback loop stimulating a delayed activation of the JNK signaling cascade, leading to release of high mobility group protein B 1 (HMGB1) and upregulation of MMP-9 [171], both molecules playing a major role in tumor growth and invasion [172]. Similarly, extracellular Hsp70 stimulated NF-kB/AP-1 signaling increased phorbol 12-myristate 13-acetate (PMA) induced activation of MMP-9 transcription in human mononuclear cells and led to enhanced invasiveness in vitro [87]. More recent data show that extracellular Hsp70 secreted from breast cancer cells could form an extracellular complex with chaperones, including Hsp90a [86]. This co-chaperone complex increased binding of Hsp90a to MMP-2, and subsequent activation of MMP-2 in vitro [86]. Inhibiting Hsp70 in conditioned media reduced MMP-2 activation and decreased breast cancer cell migration and invasion in vitro, highlighting a receptor-independent role for Hsp70 in tumor cell invasion [86].

Hsp70 could increase tumor cell invasiveness through its ability to trigger an inflammatory tumor microenvironment. Besides activating antigen-presenting cells (APCs), free extracellular Hsp70 released from ovarian cancer cells has been shown to activate neutrophils and subsequent reactive oxygen species (ROS) production via TLR2/4 signaling [173]. ROS promote angiogenesis and metastasis via stimulation of vascular endothelial growth factor production [174] and activation of MMPs [175]. This neutrophil-mediated angiogenesis could be further enhanced via interplay of extracellular Hsp70 with epithelial cells. In human bronchial epithelial cells extracellular Hsp70 has been shown to induce IL-8 and tumor necrosis factor (TNF) production, leading to the attraction and activation of neutrophils [176]. Hsp70 has been reported to bind to various epithelial and endothelial cell lines [132]. Specifically, extracellular human and mycobacterial Hsp70 has been shown to bind to the TNF receptor family member CD40 [177,178], and the binding of human Hsp70 to CD40 led to its internalization and p38 signaling in CD40-expressing HEK293T cells [177]. Interestingly, epithelial and endothelial cells have also been reported to express CD40 on their cell surface, which was upregulated at inflammatory conditions [179]. Futagami et al. showed that treatment of HUVEC cells with extracellular Hsp70 blocks CD40L-mediated inhibition of apoptosis, as well as CD40L-induced tubular formation in vitro, suggesting a critical role in tumor progression and invasion [180]. Interestingly, Hsp70 does not only act on endothelial cells, but was also shown to be released from rat 
arterial endothelial cells in an exosome-associated form, and release was further enhanced upon oxidative stress [181]. Therefore, Hsp70 released from both tumor cells and endothelial cells might provide an autocrine and paracrine regulation mechanism for promoting tumor cell invasion via stimulating release of inflammatory mediators from bystander immune cells and secretion of MMPs and IL-8 from tumor cells. Interestingly, re-invasion into the new host tissue has recently been shown to be supported by bone marrow derived cells (BMDCs) reprogrammed by TRYP2, VLA4, Hsp70, Met and Rab27a positive exosomes released from primary cancer. The exosomes elevated Met expression and provasculogenic phenotype of the BMDCs and translocation to the lung and lymph nodes, where these cells could aid angiogenesis, invasion and metastasis [182].

\section{Targeting Hsp70 in Metastatic Cancer}

Versatile functions of Hsp70 are reflected in diverse approaches which have evolved for Hsp70-based anticancer therapy, including inhibition of activity, modifying of expression levels and antitumor vaccines, extensively reviewed elsewhere [183-185]. As knock-down of Hsp70 in cervical, bladder, breast and endometrial cancer cell lines has been proven to reduce invasiveness in vitro [40,91,186,187], Hsp70-specific inhibitors could be promising in prevention of invasiveness and metastasis, as well. However, there are only a few approaches specifically targeting cells with metastatic potential through Hsp70, even though this holds true for most molecular targets in recent anticancer therapy [188].

A novel Hsp70-based vaccine has been developed to selectively eliminate highly metastatic cancer stem cells. Hsp70 complexed to tumor antigens was isolated from fusions of DC and radioresistant mammary tumor cells (Hsp70.PC-F). Treatment of mice with the Hsp70.PC-F vaccine stimulated a tumor-specific CTL response against primary and disseminated tumor and rendered the tumor more sensitive to radiotherapy [189]. This approach has a high potential in working synergistically with radiotherapy to efficiently fight primary and metastasizing tumors. Another possibility to target metastasis directly is adoptive NK cell therapy in patients with Hsp70 membrane positive tumors. It has been shown that Hsp70 membrane positive tumors are targets for NK cells in vivo [36,190-194]. Moreover, NK cells stimulated ex vivo with TKD/IL-2 have been successfully used in a Phase I clinical trial in patients with colorectal and lung carcinoma $[195,196]$. Importantly, metastatic tumors have been found to express high levels of surface Hsp70 [192,197]. These characteristics are beneficial in immunotherapy using TKD/IL-2 stimulated NK cells in combination with conventional treatments and may hold promise for eliminating metastasis in patients with Hsp70 membrane positive tumors.

Extracellular Hsp70 can act in an autocrine and paracrine fashion on tumor, immune and endothelial/epithelial cells to promote tumor cell invasion and metastasis by enhancing inflammation, angiogenesis, tumor growth, and recruitment of immunosuppressive immune cell. Therefore, targeting extracellular Hsp70 through neutralizing antibodies or small molecules interfering with Hsp70 binding to receptors may be useful to prevent invasiveness of tumors. However, the benefits of extracellular Hsp70 from the patient's point of view should be also considered in these cases. Modulating localization or activity of extracellular Hsp70 in therapeutic approaches may also help to limit cancer metastasis. A better understanding of the role of Hsp70 in tumor progression may support development of specific invasion preventing approaches. 


\section{Concluding Remarks}

Elevated expression, endosomal/lysosomal localization as well as surface exposure and release represent cancer specific features of Hsp70. A yet unresolved regulation of Hsp70 activity enables diverse functions of this molecular chaperone, affected by its localization and interacting partners. Common and unusual activities of Hsp70 may also be dependent on post-translational modifications and the actual cellular environment. Hsp70 surrounded by the tumor microenvironment has been reported to influence metastatic activity positively and negatively. Therefore, targeting of Hsp70 necessitates careful considerations in cancer therapy. While Hsp70-based vaccines and NK cell therapies would make use of antitumor properties of extracellular Hsp70, targeting intracellular Hsp70 by inhibitors in conventional anticancer treatments generally attacks pro-tumor and antitumor activities of Hsp70. Increasing immunogenicity of cancer cells that are resistant to conventional therapies could be another strategy for fighting metastatic cancer. Controlled trafficking to the tumor cell surface or release of Hsp70 may be used to stimulate the patient's immunity against the aggressive cancer cell population. For this, further investigations on Hsp70 trafficking and release, as well as on the cross-talk between tumor cells, immune cells, endothelial and epithelial cells mediated by extracellular Hsp70 in metastasis will be required. Understanding and controlling the complex function of Hsp70 in metastasizing cells will certainly require developing in vitro approaches and animal models of human cancers. Novel in vitro 3D models of invasion, enabling spatiotemporal multiparameter testing, may help further revealing the molecular mechanism of metastasis formation. Recently developed "Organs-on-Chips", described also as 3D organs grown in microfluidic chips hold promise for real time monitoring of cellular processes during metastasis.

\section{Supplementary Information}

Movie 1. Lysosomes secreting Hsp70 from mouse B16 melanoma cells. Release of Hsp70 via lysosomes fusing with the cellular membrane was visualized by TIRF microscopy. Hsp70 and LAMP-1 are displayed in green and red, respectively. The movie is playing $5 \mathrm{fps}$. Note shedding the soluble lysosomal content (Hsp70) followed by spreading of the vesicular membrane marker (LAMP-1) in the plasma membrane.

\section{Acknowledgements}

This work was funded by the European Regional Development Fund (EFRE), EFRE Internationalisierung and the state of Upper Austria.

\section{Conflicts of Interest}

The authors declare no conflict of interest. 


\section{References}

1. Kampinga, H.H.; Hageman, J.; Vos, M.J.; Kubota, H.; Tanguay, R.M.; Bruford, E.A.; Cheetham, M.E.; Chen, B.; Hightower, L.E. Guidelines for the nomenclature of the human heat shock proteins. Cell Stress Chaperones 2009, 14, 105-111.

2. Morimoto, R.I. Cells in stress: Transcriptional activation of heat shock genes. Science 1993, 259, $1409-1410$.

3. Dubois, M.F.; Bensaude, O. MAP kinase activation during heat shock in quiescent and exponentially growing mammalian cells. FEBS Lett. 1993, 324, 191-195.

4. Adler, V.; Schaffer, A.; Kim, J.; Dolan, L.; Ronai, Z. UV irradiation and heat shock mediate JNK activation via alternate pathways. J. Biol. Chem. 1995, 270, 26071-26077.

5. Soti, C.; Pál, C.; Papp, B.; Csermely, P. Molecular chaperones as regulatory elements of cellular networks. Curr. Opin. Cell Biol. 2005, 17, 210-215.

6. Xie, K.; Huang, S. Regulation of cancer metastasis by stress pathways. Clin. Exp. Metastasis 2003, 20, 31-43.

7. Santarosa, M.; Favaro, D.; Quaia, M.; Galligioni, E. Expression of heat shock protein 72 in renal cell carcinoma: Possible role and prognostic implications in cancer patients. Eur. J. Cancer 1997, 33, 873-877.

8. Nanbu, K.; Konishi, I.; Mandai, M.; Kuroda, H.; Hamid, A.A.; Komatsu, T.; Mori, T. Prognostic significance of heat shock proteins HSP70 and HSP90 in endometrial carcinomas. Cancer Detect. Prev. 1998, 22, 549-555.

9. Mosser, D.D.; Morimoto, R.I. Molecular chaperones and the stress of oncogenesis. Oncogene 2004, 23, 2907-2918.

10. Whitesell, L.; Lindquist, S. Inhibiting the transcription factor HSF1 as an anticancer strategy. Expert Opin. Ther. Targets 2009, 13, 469-478.

11. Powers, M.V.; Workman, P. Inhibitors of the heat shock response: Biology and pharmacology. FEBS Lett. 2007, 581, 3758-3769.

12. Wigmore, S.J.; Sangster, K.; McNally, S.J.; Harrison, E.M.; Ross, J.A.; Fearon, K.C.H.; Garden, O.J. De-repression of heat shock transcription factor-1 in interleukin-6-treated hepatocytes is mediated by downregulation of glycogen synthase kinase 3beta and MAPK/ERK-1. Int. J. Mol. Med. 2007, 19, 413-420.

13. Nylandsted, J.; Rohde, M.; Brand, K.; Bastholm, L.; Elling, F.; Jäättelä, M. Selective depletion of heat shock protein 70 (Hsp70) activates a tumor-specific death program that is independent of caspases and bypasses Bcl-2. Proc. Natl. Acad. Sci. USA 2000, 97, 7871-7876.

14. Wei, Y.Q.; Zhao, X.; Kariya, Y.; Teshigawara, K.; Uchida, A. Inhibition of proliferation and induction of apoptosis by abrogation of heat-shock protein (HSP) 70 expression in tumor cells. Cancer Immunol. Immunother. 1995, 40, 73-78.

15. Kaur, J.; Kaur, J.; Ralhan, R. Induction of apoptosis by abrogation of HSP70 expression in human oral cancer cells. Int. J. Cancer J. Int. Cancer 2000, 85, 1-5.

16. Jäättelä, M. Over-expression of hsp70 confers tumorigenicity to mouse fibrosarcoma cells. Int. J. Cancer 1995, 60, 689-693. 
17. Seo, J.S.; Park, Y.M.; Kim, J.I.; Shim, E.H.; Kim, C.W.; Jang, J.J.; Kim, S.H.; Lee, W.H. T cell lymphoma in transgenic mice expressing the human Hsp70 gene. Biochem. Biophys. Res. Commun. 1996, 218, 582-587.

18. Volloch, V.Z.; Sherman, M.Y. Oncogenic potential of Hsp72. Oncogene 1999, 18, 3648-3651.

19. Gurbuxani, S.; Bruey, J.M.; Fromentin, A.; Larmonier, N.; Parcellier, A.; Jäättelä, M.; Martin, F.; Solary, E.; Garrido, C. Selective depletion of inducible HSP70 enhances immunogenicity of rat colon cancer cells. Oncogene 2001, 20, 7478-7485.

20. Ralhan, R.; Kaur, J. Differential expression of Mr 70,000 heat shock protein in normal, premalignant, and malignant human uterine cervix. Clin. Cancer Res. 1995, 1, 1217-1222.

21. Lazaris, A.C.; Theodoropoulos, G.E.; Aroni, K.; Saetta, A.; Davaris, P.S. Immunohistochemical expression of C-myc oncogene, heat shock protein 70 and HLA-DR molecules in malignant cutaneous melanoma. Virchows Arch. Int. J. Pathol. 1995, 426, 461-467.

22. Kaur, J.; Srivastava, A.; Ralhan, R. Expression of 70-kDa heat shock protein in oral lesions: Marker of biological stress or pathogenicity. Oral Oncol. 1998, 34, 496-501.

23. Syrigos, K.N.; Harrington, K.J.; Karayiannakis, A.J.; Sekara, E.; Chatziyianni, E.; Syrigou, E.I.; Waxman, J. Clinical significance of heat shock protein-70 expression in bladder cancer. Urology 2003, 61, 677-680.

24. Abe, M.; Manola, J.B.; Oh, W.K.; Parslow, D.L.; George, D.J.; Austin, C.L.; Kantoff, P.W. Plasma levels of heat shock protein 70 in patients with prostate cancer: A potential biomarker for prostate cancer. Clin. Prostate Cancer 2004, 3, 49-53.

25. Chuma, M.; Sakamoto, M.; Yamazaki, K.; Ohta, T.; Ohki, M.; Asaka, M.; Hirohashi, S. Expression profiling in multistage hepatocarcinogenesis: Identification of HSP70 as a molecular marker of early hepatocellular carcinoma. Hepatology 2003, 37, 198-207.

26. Ciocca, D.R.; Clark, G.M.; Tandon, A.K.; Fuqua, S.A.; Welch, W.J.; McGuire, W.L. Heat shock protein hsp70 in patients with axillary lymph node-negative breast cancer: Prognostic implications. J. Natl. Cancer Inst. 1993, 85, 570-574.

27. Thanner, F.; Sütterlin, M.W.; Kapp, M.; Rieger, L.; Kristen, P.; Dietl, J.; Gassel, A.M.; Müller, T. Heat-shock protein 70 as a prognostic marker in node-negative breast cancer. Anticancer Res. 2003, 23, 1057-1062.

28. Thomas, X.; Campos, L.; Mounier, C.; Cornillon, J.; Flandrin, P.; Le, Q.-H.; Piselli, S.; Guyotat, D. Expression of heat-shock proteins is associated with major adverse prognostic factors in acute myeloid leukemia. Leuk. Res. 2005, 29, 1049-1058.

29. Sun, X.F.; Zhang, H.; Carstensen, J.; Jansson, A.; Nordenskjöld, B. Heat shock protein 72/73 in relation to cytoplasmic p53 expression and prognosis in colorectal adenocarcinomas. Int. J. Cancer 1997, 74, 600-604.

30. Kawanishi, K.; Shiozaki, H.; Doki, Y.; Sakita, I.; Inoue, M.; Yano, M.; Tsujinaka, T.; Shamma, A.; Monden, M. Prognostic significance of heat shock proteins 27 and 70 in patients with squamous cell carcinoma of the esophagus. Cancer 1999, 85, 1649-1657.

31. Shiozaki, H.; Doki, Y.; Kawanishi, K.; Shamma, A.; Yano, M.; Inoue, M.; Monden, M. Clinical application of malignancy potential grading as a prognostic factor of human esophageal cancers. Surgery 2000, 127, 552-561. 
32. Maehara, Y.; Oki, E.; Abe, T.; Tokunaga, E.; Shibahara, K.; Kakeji, Y.; Sugimachi, K. Overexpression of the heat shock protein HSP70 family and p53 protein and prognosis for patients with gastric cancer. Oncology 2000, 58, 144-151.

33. Nakajima, M.; Kato, H.; Miyazaki, T.; Fukuchi, M.; Masuda, N.; Fukai, Y.; Sohda, M.; Ahmad, F.; Kuwano, H. Tumor immune systems in esophageal cancer with special reference to heat-shock protein 70 and humoral immunity. Anticancer Res. 2009, 29, 1595-1606.

34. Trieb, K.; Lechleitner, T.; Lang, S.; Windhager, R.; Kotz, R.; Dirnhofer, S. Heat shock protein 72 expression in osteosarcomas correlates with good response to neoadjuvant chemotherapy. Hum. Pathol. 1998, 29, 1050-1055.

35. Multhoff, G.; Botzler, C.; Wiesnet, M.; Müller, E.; Meier, T.; Wilmanns, W.; Issels, R.D. A stress-inducible 72-kDa heat-shock protein (HSP72) is expressed on the surface of human tumor cells, but not on normal cells. Int. J. Cancer 1995, 61, 272-279.

36. Multhoff, G.; Botzler, C.; Jennen, L.; Schmidt, J.; Ellwart, J.; Issels, R. Heat shock protein 72 on tumor cells: A recognition structure for natural killer cells. J. Immunol. 1997, 158, 4341-4350.

37. Gastpar, R.; Gehrmann, M.; Bausero, M.A.; Asea, A.; Gross, C.; Schroeder, J.A.; Multhoff, G. Heat shock protein 70 surface-positive tumor exosomes stimulate migratory and cytolytic activity of natural killer cells. Cancer Res. 2005, 65, 5238-5247.

38. Korbelik, M.; Sun, J.; Cecic, I. Photodynamic therapy-induced cell surface expression and release of heat shock proteins: Relevance for tumor response. Cancer Res. 2005, 65, 1018-1026.

39. Asea, A.; Kraeft, S.K.; Kurt-Jones, E.A.; Stevenson, M.A.; Chen, L.B.; Finberg, R.W.; Koo, G.C.; Calderwood, S.K. HSP70 stimulates cytokine production through a CD14-dependant pathway, demonstrating its dual role as a chaperone and cytokine. Nat. Med. 2000, 6, 435-442.

40. Garg, M.; Kanojia, D.; Saini, S.; Suri, S.; Gupta, A.; Surolia, A.; Suri, A. Germ cell-specific heat shock protein 70-2 is expressed in cervical carcinoma and is involved in the growth, migration, and invasion of cervical cells. Cancer 2010, 116, 3785-3796.

41. Simard, J.P.; Reynolds, D.N.; Kraguljac, A.P.; Smith, G.S.T.; Mosser, D.D. Overexpression of HSP70 inhibits cofilin phosphorylation and promotes lymphocyte migration in heat-stressed cells. J. Cell Sci. 2011, 124, 2367-2374.

42. Chiu, C.-C.; Lin, C.-Y.; Lee, L.-Y.; Chen, Y.-J.; Lu, Y.-C.; Wang, H.-M.; Liao, C.-T.; Chang, J.T.-C.; Cheng, A.-J. Molecular Chaperones as a Common Set of Proteins That Regulate the Invasion Phenotype of Head and Neck Cancer. Clin. Cancer Res. 2011, 17, 4629-4641.

43. Kluger, H.M.; Lev, D.C.; Kluger, Y.; McCarthy, M.M.; Kiriakova, G.; Camp, R.L.; Rimm, D.L.; Price, J.E. Using a Xenograft Model of Human Breast Cancer Metastasis to Find Genes Associated with Clinically Aggressive Disease. Cancer Res. 2005, 65, 5578-5587.

44. Becker, B.; Multhoff, G.; Farkas, B.; Wild, P.-J.; Landthaler, M.; Stolz, W.; Vogt, T. Induction of Hsp90 protein expression in malignant melanomas and melanoma metastases. Exp. Dermatol. 2004, 13, 27-32.

45. Gabai, V.L.; Yaglom, J.A.; Waldman, T.; Sherman, M.Y. Heat shock protein Hsp72 controls oncogene-induced senescence pathways in cancer cells. Mol. Cell. Biol. 2009, 29, 559-569.

46. Gurbuxani, S.; Schmitt, E.; Cande, C.; Parcellier, A.; Hammann, A.; Daugas, E.; Kouranti, I.; Spahr, C.; Pance, A.; Kroemer, G.; Garrido, C. Heat shock protein 70 binding inhibits the nuclear import of apoptosis-inducing factor. Oncogene 2003, 22, 6669-6678. 
47. Rohde, M.; Daugaard, M.; Jensen, M.H.; Helin, K.; Nylandsted, J.; Jäättelä, M. Members of the heat-shock protein 70 family promote cancer cell growth by distinct mechanisms. Genes Dev. 2005, 19, 570-582.

48. Gabai, V.L.; Budagova, K.R.; Sherman, M.Y. Increased expression of the major heat shock protein Hsp72 in human prostate carcinoma cells is dispensable for their viability but confers resistance to a variety of anticancer agents. Oncogene 2005, 24, 3328-3338.

49. Wang, X.-P.; Wang, Q.-X.; Ying, X.-P. Correlation between clinicopathology and expression of heat shock protein 72 and glycoprotein 96 in human gastric adenocarcinoma. Tohoku J. Exp. Med. 2007, 212, 35-41.

50. Calderwood, S.K. Molecular Cochaperones: Tumor Growth and Cancer Treatment. Scientifica 2013, 2013, 1-13.

51. Dorsey, W.C.; Tchounwou, P.B. CYP1a1, HSP70, P53, and c-fos expression in human liver carcinoma cells (HepG2) exposed to pentachlorophenol. Biomed. Sci. Instrum. 2003, 39, 389-396.

52. Hwang, T.S.; Han, H.S.; Choi, H.K.; Lee, Y.J.; Kim, Y.-J.; Han, M.-Y.; Park, Y.-M. Differential, stage-dependent expression of Hsp70, Hsp110 and Bcl-2 in colorectal cancer. J. Gastroenterol. Hepatol. 2003, 18, 690-700.

53. Zorzi, E.; Bonvini, P. Inducible Hsp70 in the regulation of cancer cell survival: Analysis of chaperone induction, expression and activity. Cancers 2011, 3, 3921-3956.

54. Fidler, I.J.; Nicolson, G.L. Fate of recirculating B16 melanoma metastatic variant cells in parabiotic syngeneic recipients. J. Natl. Cancer Inst. 1977, 58, 1867-1872.

55. Liotta, L.A.; Vembu, D.; Saini, R.K.; Boone, C. In vivo monitoring of the death rate of artificial murine pulmonary micrometastases. Cancer Res. 1978, 38, 1231-1236.

56. Wang, X.; Chen, W.; Li, X.; Lin, H.; Wang, Q. Heat shock protein 72 associated with CD44v6 in human colonic adenocarcinoma. Cell Biol. Int. 2008, 32, 860-864.

57. Ponta, H.; Sherman, L.; Herrlich, P.A. CD44: From adhesion molecules to signalling regulators. Nat. Rev. Mol. Cell Biol. 2003, 4, 33-45.

58. Jäättelä, M.; Wissing, D.; Bauer, P.A.; Li, G.C. Major heat shock protein hsp70 protects tumor cells from tumor necrosis factor cytotoxicity. EMBO J. 1992, 11, 3507-3512.

59. Jäättelä, M.; Wissing, D.; Kokholm, K.; Kallunki, T.; Egeblad, M. Hsp70 exerts its anti-apoptotic function downstream of caspase-3-like proteases. EMBO J. 1998, 17, 6124-6134.

60. Jäättelä, M.; Wissing, D. Heat-shock proteins protect cells from monocyte cytotoxicity: Possible mechanism of self-protection. J. Exp. Med. 1993, 177, 231-236.

61. Simon, M.M.; Reikerstorfer, A.; Schwarz, A.; Krone, C.; Luger, T.A.; Jäättelä, M.; Schwarz, T. Heat shock protein 70 overexpression affects the response to ultraviolet light in murine fibroblasts. Evidence for increased cell viability and suppression of cytokine release. J. Clin. Invest. 1995, 95, 926-933.

62. Mosser, D.D.; Caron, A.W.; Bourget, L.; Denis-Larose, C.; Massie, B. Role of the human heat shock protein hsp70 in protection against stress-induced apoptosis. Mol. Cell. Biol. 1997, 17, 5317-5327.

63. Buzzard, K.A.; Giaccia, A.J.; Killender, M.; Anderson, R.L. Heat shock protein 72 modulates pathways of stress-induced apoptosis. J. Biol. Chem. 1998, 273, 17147-17153. 
64. Vayssier, M.; Banzet, N.; François, D.; Bellmann, K.; Polla, B.S. Tobacco smoke induces both apoptosis and necrosis in mammalian cells: Differential effects of HSP70. Am. J. Physiol. 1998, 275, L771-L779.

65. Nylandsted, J.; Gyrd-Hansen, M.; Danielewicz, A.; Fehrenbacher, N.; Lademann, U.; Høyer-Hansen, M.; Weber, E.; Multhoff, G.; Rohde, M.; Jäättelä, M. Heat shock protein 70 promotes cell survival by inhibiting lysosomal membrane permeabilization. J. Exp. Med. 2004, 200, 425-435.

66. Mosser, D.D.; Caron, A.W.; Bourget, L.; Meriin, A.B.; Sherman, M.Y.; Morimoto, R.I.; Massie, B. The chaperone function of hsp70 is required for protection against stress-induced apoptosis. Mol. Cell. Biol. 2000, 20, 7146-7159.

67. Gabai, V.L.; Meriin, A.B.; Mosser, D.D.; Caron, A.W.; Rits, S.; Shifrin, V.I.; Sherman, M.Y. Hsp70 prevents activation of stress Kinases a novel pathway of cellular thermotolerance. J. Biol. Chem. 1997, 272, 18033-18037.

68. Park, H.-S.; Cho, S.-G.; Kim, C.K.; Hwang, H.S.; Noh, K.T.; Kim, M.-S.; Huh, S.-H.; Kim, M.J.; Ryoo, K.; Kim, E.K.; et al. Heat shock protein Hsp72 is a negative regulator of apoptosis signal-regulating Kinase 1. Mol. Cell. Biol. 2002, 22, 7721-7730.

69. Park, H.-S.; Lee, J.-S.; Huh, S.-H.; Seo, J.-S.; Choi, E.-J. Hsp72 functions as a natural inhibitory protein of c-Jun $N$-terminal kinase. EMBO J. 2001, 20, 446-456.

70. Lee, J.-S.; Lee, J.-J.; Seo, J.-S. HSP70 Deficiency Results in Activation of c-Jun $N$-terminal Kinase, Extracellular Signal-regulated Kinase, and Caspase-3 in Hyperosmolarity-induced Apoptosis. J. Biol. Chem. 2005, 280, 6634-6641.

71. Yaglom, J.; O'Callaghan-Sunol, C.; Gabai, V.; Sherman, M.Y. Inactivation of dual-specificity phosphatases is involved in the regulation of extracellular signal-regulated kinases by heat shock and hsp72. Mol. Cell. Biol. 2003, 23, 3813-3824.

72. Song, J.; Takeda, M.; Morimoto, R.I. Bag1-Hsp70 mediates a physiological stress signalling pathway that regulates Raf-1/ERK and cell growth. Nat. Cell Biol. 2001, 3, 276-282.

73. Yaglom, J.A.; Gabai, V.L.; Sherman, M.Y. High levels of heat shock protein Hsp72 in cancer cells suppress default senescence pathways. Cancer Res. 2007, 67, 2373-2381.

74. Beere, H.M.; Wolf, B.B.; Cain, K.; Mosser, D.D.; Mahboubi, A.; Kuwana, T.; Tailor, P.; Morimoto, R.I.; Cohen, G.M.; Green, D.R. Heat-shock protein 70 inhibits apoptosis by preventing recruitment of procaspase-9 to the Apaf-1 apoptosome. Nat. Cell Biol. 2000, 2, 469-475.

75. Ravagnan, L.; Gurbuxani, S.; Susin, S.A.; Maisse, C.; Daugas, E.; Zamzami, N.; Mak, T.; Jäättelä, M.; Penninger, J.M.; Garrido, C.; et al. Heat-shock protein 70 antagonizes apoptosisinducing factor. Nat. Cell Biol. 2001, 3, 839-843.

76. Doulias, P.-T.; Kotoglou, P.; Tenopoulou, M.; Keramisanou, D.; Tzavaras, T.; Brunk, U.; Galaris, D.; Angelidis, C. Involvement of heat shock protein-70 in the mechanism of hydrogen peroxide-induced DNA damage: The role of lysosomes and iron. Free Radic. Biol. Med. 2007, 42, 567-577.

77. Schmitt, E.; Gehrmann, M.; Brunet, M.; Multhoff, G.; Garrido, C. Intracellular and extracellular functions of heat shock proteins: Repercussions in cancer therapy. J. Leukoc. Biol. 2007, 81, 15-27.

78. Felding-Habermann, B. Integrin adhesion receptors in tumor metastasis. Clin. Exp. Metastasis 2003, 20, 203-213. 
79. Mehlen, P.; Puisieux, A. Metastasis: A question of life or death. Nat. Rev. Cancer 2006, 6, 449-458.

80. Gyrd-Hansen, M.; Nylandsted, J.; Jäättelä, M. Heat shock protein 70 promotes cancer cell viability by safeguarding lysosomal integrity. Cell Cycle 2004, 3, 1484-1485.

81. Jang, K.W.; Lee, J.E.; Kim, S.Y.; Kang, M.-W.; Na, M.H.; Lee, C.S.; Song, K.S.; Lim, S.P. The $C$-terminus of Hsp70-interacting protein promotes Met receptor degradation. J. Thorac. Oncol. 2011, 6, 679-687.

82. Mao, H.; Li, F.; Ruchalski, K.; Mosser, D.D.; Schwartz, J.H.; Wang, Y.; Borkan, S.C. Hsp72 inhibits focal adhesion kinase degradation in atp-depleted renal epithelial cells. J. Biol. Chem. 2003, 278, 18214-18220.

83. Hofmann, U.B.; Houben, R.; Bröcker, E.-B.; Becker, J.C. Role of matrix metalloproteinases in melanoma cell invasion. Biochimie 2005, 87, 307-314.

84. Abraham, R.; Schäfer, J.; Rothe, M.; Bange, J.; Knyazev, P.; Ullrich, A. Identification of MMP-15 as an anti-apoptotic factor in cancer cells. J. Biol. Chem. 2005, 280, 34123-34132.

85. Strand, S.; Vollmer, P.; van den Abeelen, L.; Gottfried, D.; Alla, V.; Heid, H.; Kuball, J.; Theobald, M.; Galle, P.R.; Strand, D. Cleavage of CD95 by matrix metalloproteinase-7 induces apoptosis resistance in tumour cells. Oncogene 2004, 23, 3732-3736.

86. Sims, J.D.; McCready, J.; Jay, D.G. Extracellular heat shock protein (Hsp)70 and Hsp90 $\alpha$ assist in matrix metalloproteinase-2 activation and breast cancer cell migration and invasion. PLoS One 2011, 6, e18848.

87. Lee, K.-J.; Kim, Y.M.; Kim, D.Y.; Jeoung, D.; Han, K.; Lee, S.-T.; Lee, Y.-S.; Park, K.H.; Park, J.H.; Kim, D.J.; et al. Release of heat shock protein 70 (Hsp70) and the effects of extracellular Hsp70 on matric metalloproteinase-9 expression in human monocytic U937 cells. Exp. Mol. Med. 2006, 38, 364-374.

88. Cannito, S.; Novo, E.; Compagnone, A.; Valfrè di Bonzo, L.; Busletta, C.; Zamara, E.; Paternostro, C.; Povero, D.; Bandino, A.; Bozzo, F.; et al. Redox mechanisms switch on hypoxia-dependent epithelial-mesenchymal transition in cancer cells. Carcinogenesis 2008, 29, 2267-2278.

89. Zhong, Q.; Zhou, B.; Ann, D.K.; Minoo, P.; Liu, Y.; Banfalvi, A.; Krishnaveni, M.S.; Dubourd, M.; Demaio, L.; Willis, B.C.; et al. Role of endoplasmic reticulum stress in epithelial-mesenchymal transition of alveolar epithelial cells: Effects of misfolded surfactant protein. Am. J. Respir. Cell Mol. Biol. 2011, 45, 498-509.

90. Canöz, O.; Belenli, O.; Patiroglu, T.E. General features of gastric carcinomas and comparison of HSP70 and NK cell immunoreactivity with prognostic factors. Pathol. Oncol. Res. 2002, 8, 262-269.

91. Teng, Y.; Ngoka, L.; Mei, Y.; Lesoon, L.; Cowell, J.K. HSP90 and HSP70 proteins are essential for stabilization and activation of WASF3 metastasis-promoting protein. J. Biol. Chem. 2012, 287, 10051-10059.

92. Birchmeier, C.; Birchmeier, W.; Gherardi, E.; vande Woude, G.F. Met, metastasis, motility and more. Nat. Rev. Mol. Cell Biol. 2003, 4, 915-925.

93. Li, Y.; Kang, X.; Wang, Q. HSP70 decreases receptor-dependent phosphorylation of Smad2 and blocks TGF- $\beta$-induced epithelial-mesenchymal transition. J. Genet. Genomics 2011, 38, 111-116. 
94. Mao, H.; Wang, Y.; Li, Z.; Ruchalski, K.L.; Yu, X.; Schwartz, J.H.; Borkan, S.C. Hsp72 interacts with paxillin and facilitates the reassembly of focal adhesions during recovery from ATP depletion. J. Biol. Chem. 2004, 279, 15472-15480.

95. Willmer, T.; Contu, L.; Blatch, G.L.; Edkins, A.L. Knockdown of Hop downregulates RhoC expression, and decreases pseudopodia formation and migration in cancer cell lines. Cancer Lett. 2013, 328, 252-260.

96. Boroughs, L.K.; Antonyak, M.A.; Johnson, J.L.; Cerione, R.A. A unique role for heat shock protein 70 and its binding partner tissue transglutaminase in cancer cell migration. J. Biol. Chem. 2011, 286, 37094-37107.

97. Sossey-Alaoui, K.; Safina, A.; Li, X.; Vaughan, M.M.; Hicks, D.G.; Bakin, A.V.; Cowell, J.K. Down-regulation of WAVE3, a metastasis promoter gene, inhibits invasion and metastasis of breast cancer cells. Am. J. Pathol. 2007, 170, 2112-2121.

98. Sossey-Alaoui, K.; Li, X.; Ranalli, T.A.; Cowell, J.K. WAVE3-mediated cell migration and lamellipodia formation are regulated downstream of phosphatidylinositol 3-Kinase. J. Biol. Chem. 2005, 280, 21748-21755.

99. Teng, Y.; Ren, M.Q.; Cheney, R.; Sharma, S.; Cowell, J.K. Inactivation of the WASF3 gene in prostate cancer cells leads to suppression of tumorigenicity and metastases. Br. J. Cancer $\mathbf{2 0 1 0}$, 103, 1066-1075.

100. Iwasaki, M.; Homma, S.; Hishiya, A.; Dolezal, S.J.; Reed, J.C.; Takayama, S. BAG3 regulates motility and adhesion of epithelial cancer cells. Cancer Res. 2007, 67, 10252-10259.

101. Suzuki, M.; Iwasaki, M.; Sugio, A.; Hishiya, A.; Tanaka, R.; Endo, T.; Takayama, S.; Saito, T. BAG3 (BCL2-associated athanogene 3) interacts with MMP-2 to positively regulate invasion by ovarian carcinoma cells. Cancer Lett. 2011, 303, 65-71.

102. Song, X.; Wang, X.; Zhuo, W.; Shi, H.; Feng, D.; Sun, Y.; Liang, Y.; Fu, Y.; Zhou, D.; Luo, Y. The Regulatory mechanism of extracellular Hsp90 $\alpha$ on matrix metalloproteinase-2 processing and tumor angiogenesis. J. Biol. Chem. 2010, 285, 40039-40049.

103. Walsh, N.; Larkin, A.; Swan, N.; Conlon, K.; Dowling, P.; McDermott, R.; Clynes, M. RNAi knockdown of Hop (Hsp70/Hsp90 organising protein) decreases invasion via MMP-2 down regulation. Cancer Lett. 2011, 306, 180-189.

104. Deryugina, E.I.; Quigley, J.P. Matrix metalloproteinases and tumor metastasis. Cancer Metastasis Rev. 2006, 25, 9-34.

105. Leber, M.F.; Efferth, T. Molecular principles of cancer invasion and metastasis. Int. J. Oncol. 2009, 34, 881-895.

106. Chetty, C.; Vanamala, S.K.; Gondi, C.S.; Dinh, D.H.; Gujrati, M.; Rao, J.S. MMP-9 induces CD44 cleavage and CD44 mediated cell migration in glioblastoma xenograft cells. Cell. Signal. 2012, 24, 549-559.

107. Sherman, M.; Multhoff, G. Heat shock proteins in cancer. Ann. NY Acad. Sci. 2007, 1113, 192-201.

108. Arispe, N.; Doh, M.; Simakova, O.; Kurganov, B.; de Maio, A. Hsc70 and Hsp70 interact with phosphatidylserine on the surface of $\mathrm{PC} 12$ cells resulting in a decrease of viability. FASEB J. 2004, 18, 1636-1645.

109. Arispe, N.; Doh, M.; de Maio, A. Lipid interaction differentiates the constitutive and stress-induced heat shock proteins Hsc70 and Hsp70. Cell Stress Chaperones 2002, 7, 330-338. 
110. Bausero, M.A.; Gastpar, R.; Multhoff, G.; Asea, A. Alternative mechanism by which IFN-gamma enhances tumor recognition: Active release of heat shock protein $72 . \mathrm{J}$. Immunol. 2005, 175, 2900-2912.

111. Broquet, A.H.; Thomas, G.; Masliah, J.; Trugnan, G.; Bachelet, M. Expression of the molecular chaperone Hsp70 in detergent-resistant microdomains correlates with its membrane delivery and release. J. Biol. Chem. 2003, 278, 21601-21606.

112. Hunter-Lavin, C.; Davies, E.L.; Bacelar, M.M.F.V.G.; Marshall, M.J.; Andrew, S.M.; Williams, J.H.H. Hsp70 release from peripheral blood mononuclear cells. Biochem. Biophys. Res. Commun. 2004, 324, 511-517.

113. Lancaster, G.I.; Febbraio, M.A. Exosome-dependent trafficking of HSP70: A novel secretory pathway for cellular stress proteins. J. Biol. Chem. 2005, 280, 23349-23355.

114. Mambula, S.S.; Calderwood, S.K. Heat shock protein 70 is secreted from tumor cells by a nonclassical pathway involving lysosomal endosomes. J. Immunol. 2006, 177, 7849-7857.

115. Lv, L.-H.; Wan, Y.-L.; Lin, Y.; Zhang, W.; Yang, M.; Li, G.-L.; Lin, H.-M.; Shang, C.-Z.; Chen, Y.-J.; Min, J. Anticancer drugs cause release of exosomes with heat shock proteins from human hepatocellular carcinoma cells that elicit effective natural killer cell antitumor responses in vitro. J. Biol. Chem. 2012, 287, 15874-15885.

116. Radons, J.; Multhoff, G. Immunostimulatory functions of membrane-bound and exported heat shock protein 70. Exerc. Immunol. Rev. 2005, 11, 17-33.

117. Evdonin, A.L.; Guzhova, I.V.; Margulis, B.A.; Medvedeva, N.D. Extracellular heat shock protein 70 mediates heat stress-induced epidermal growth factor receptor transactivation in A431 carcinoma cells. FEBS Lett. 2006, 580, 6674-6678.

118. Juhász, K.; Thuenauer, R.; Spachinger, A.; Duda, E.; Horváth, I.; Vígh, L.; Sonnleitner, A.; Balogi, Z. Lysosomal rerouting of Hsp70 trafficking as a potential immune activating tool for targeting melanoma. Curr. Pharm. Des. 2013, 19, 430-440.

119. Petersen, N.H.T.; Kirkegaard, T.; Olsen, O.D.; Jäättelä, M. Connecting Hsp70, sphingolipid metabolism and lysosomal stability. Cell Cycle 2010, 9, 2305-2309.

120. Kurz, T.; Brunk, U.T. Autophagy of HSP70 and chelation of lysosomal iron in a non-redox-active form. Autophagy 2009, 5, 93-95.

121. Yang, Y.; Rao, R.; Shen, J.; Tang, Y.; Fiskus, W.; Nechtman, J.; Atadja, P.; Bhalla, K. Role of acetylation and extracellular location of heat shock protein 90alpha in tumor cell invasion. Cancer Res. 2008, 68, 4833-4842.

122. Kirkegaard, T.; Roth, A.G.; Petersen, N.H.T.; Mahalka, A.K.; Olsen, O.D.; Moilanen, I.; Zylicz, A.; Knudsen, J.; Sandhoff, K.; Arenz, C.; et al. Hsp70 stabilizes lysosomes and reverts Niemann-Pick disease-associated lysosomal pathology. Nature 2010, 463, 549-553.

123. Fehrenbacher, N.; Jäättelä, M. Lysosomes as targets for cancer therapy. Cancer Res. 2005, 65, 2993-2995.

124. Vasiljeva, O.; Reinheckel, T.; Peters, C.; Turk, D.; Turk, V.; Turk, B. Emerging roles of cysteine cathepsins in disease and their potential as drug targets. Curr. Pharm. Des. 2007, 13, 387-403.

125. Joyce, J.A.; Baruch, A.; Chehade, K.; Meyer-Morse, N.; Giraudo, E.; Tsai, F.-Y.; Greenbaum, D.C.; Hager, J.H.; Bogyo, M.; Hanahan, D. Cathepsin cysteine proteases are effectors of invasive growth and angiogenesis during multistage tumorigenesis. Cancer Cell 2004, 5, 443-453. 
126. Tu, C.; Ortega-Cava, C.F.; Chen, G.; Fernandes, N.D.; Cavallo-Medved, D.; Sloane, B.F.; Band, V.; Band, H. Lysosomal cathepsin B participates in the podosome-mediated extracellular matrix degradation and invasion via secreted lysosomes in v-Src fibroblasts. Cancer Res. 2008, 68, 9147-9156.

127. Juhasz, K.; Lehner, M.; Hesse, J.; Haselgruebler, T.; Balogi, Z. Center for Advanced Bioanalysis $\mathrm{GmbH}$, Linz, Austria. Unpublished work, 2013.

128. Yano, Y.; Yano, A.; Oishi, S.; Sugimoto, Y.; Tsujimoto, G.; Fujii, N.; Matsuzaki, K. Coiled-coil tag-Probe system for quick labeling of membrane receptors in living cell. ACS Chem. Biol. 2008, 3, 341-345.

129. Vega, V.L.; Charles, W.; de Maio, A. A new feature of the stress response: Increase in endocytosis mediated by Hsp70. Cell Stress Chaperones 2010, 15, 517-527.

130. Vega, V.L.; Rodriguez-Silva, M.; Frey, T.; Gehrmann, M.; Diaz, J.C.; Steinem, C.; Multhoff, G.; Arispe, N.; de Maio, A. Hsp70 translocates into the plasma membrane after stress and is released into the extracellular environment in a membrane-associated form that activates macrophages. J. Immunol. 2008, 180, 4299-4307.

131. Delneste, Y.; Magistrelli, G.; Gauchat, J.-F.; Haeuw, J.-F.; Aubry, J.-P.; Nakamura, K.; Kawakami-Honda, N.; Goetsch, L.; Sawamura, T.; Bonnefoy, J.-Y. Involvement of LOX-1 in dendritic cell-mediated antigen cross-presentation. Immunity 2002, 17, 353-362.

132. Thériault, J.R.; Mambula, S.S.; Sawamura, T.; Stevenson, M.A.; Calderwood, S.K. Extracellular HSP70 binding to surface receptors present on antigen presenting cells and endothelial/epithelial cells. FEBS Lett. 2005, 579, 1951-1960.

133. Basu, S.; Binder, R.J.; Ramalingam, T.; Srivastava, P.K. CD91 is a common receptor for heat shock proteins gp96, hsp90, hsp70, and calreticulin. Immunity 2001, 14, 303-313.

134. Thériault, J.R.; Adachi, H.; Calderwood, S.K. Role of scavenger receptors in the binding and internalization of heat shock protein 70. J. Immunol. 2006, 177, 8604-8611.

135. Bendz, H.; Ruhland, S.C.; Pandya, M.J.; Hainzl, O.; Riegelsberger, S.; Brauchle, C.; Mayer, M.P.; Buchner, J.; Issels, R.D.; Noessner, E. Human heat shock protein 70 enhances tumor antigen presentation through complex formation and intracellular antigen delivery without innate immune signaling. J. Biol. Chem. 2007, 282, 31688-31702.

136. Noessner, E.; Gastpar, R.; Milani, V.; Brandl, A.; Hutzler, P.J.; Kuppner, M.C.; Roos, M.; Kremmer, E.; Asea, A.; Calderwood, S.K.; et al. Tumor-derived heat shock protein 70 peptide complexes are cross-presented by human dendritic cells. J. Immunol. 2002, 169, 5424-5432.

137. Murshid, A.; Gong, J.; Calderwood, S.K. The role of heat shock proteins in antigen cross presentation. Front. Immunol. 2012, 3, 63.

138. Arnold-Schild, D.; Hanau, D.; Spehner, D.; Schmid, C.; Rammensee, H.G.; de la Salle, H.; Schild, H. Cutting edge: Receptor-mediated endocytosis of heat shock proteins by professional antigen-presenting cells. J. Immunol. 1999, 162, 3757-3760.

139. Schild, H.; Arnold-Schild, D.; Lammert, E.; Rammensee, H.G. Stress proteins and immunity mediated by cytotoxic T lymphocytes. Curr. Opin. Immunol. 1999, 11, 109-113.

140. Enomoto, Y.; Bharti, A.; Khaleque, A.A.; Song, B.; Liu, C.; Apostolopoulos, V.; Xing, P.; Calderwood, S.K.; Gong, J. Enhanced immunogenicity of heat shock protein 70 peptide complexes from dendritic cell-tumor fusion cells. J. Immunol. 2006, 177, 5946-5955. 
141. Stangl, S.; Gehrmann, M.; Riegger, J.; Kuhs, K.; Riederer, I.; Sievert, W.; Hube, K.; Mocikat, R.; Dressel, R.; Kremmer, E.; et al. Targeting membrane heat-shock protein 70 (Hsp70) on tumors by cmHsp70.1 antibody. Proc. Natl. Acad. Sci. USA 2011, 108, 733-738.

142. Multhoff, G.; Pfister, K.; Gehrmann, M.; Hantschel, M.; Gross, C.; Hafner, M.; Hiddemann, W. A 14-mer Hsp70 peptide stimulates natural killer (NK) cell activity. Cell Stress Chaperones 2001, 6, 337-344.

143. Gross, C.; Schmidt-Wolf, I.G.; Nagaraj, S.; Gastpar, R.; Ellwart, J.; Kunz-Schughart, L.A.; Multhoff, G. Heat shock protein 70-reactivity is associated with increased cell surface density of CD94/CD56 on primary natural killer cells. Cell Stress Chaperones 2003, 8, 348-360.

144. Gastpar, R.; Gross, C.; Rossbacher, L.; Ellwart, J.; Riegger, J.; Multhoff, G. The cell surface-localized heat shock protein 70 epitope TKD induces migration and cytolytic activity selectively in human NK cells. J. Immunol. 2004, 172, 972-980.

145. Figueiredo, C.; Wittmann, M.; Wang, D.; Dressel, R.; Seltsam, A.; Blasczyk, R.; Eiz-Vesper, B. Heat shock protein 70 (HSP70) induces cytotoxicity of T-helper cells. Blood 2009, 113, 3008-3016.

146. Clayton, A.; Turkes, A.; Navabi, H.; Mason, M.D.; Tabi, Z. Induction of heat shock proteins in B-cell exosomes. J. Cell Sci. 2005, 118, 3631-3638.

147. Asea, A.; Rehli, M.; Kabingu, E.; Boch, J.A.; Bare, O.; Auron, P.E.; Stevenson, M.A.; Calderwood, S.K. Novel signal transduction pathway utilized by extracellular HSP70: Role of toll-like receptor (TLR) 2 and TLR4. J. Biol. Chem. 2002, 277, 15028-15034.

148. Vabulas, R.M.; Ahmad-Nejad, P.; Ghose, S.; Kirschning, C.J.; Issels, R.D.; Wagner, H. HSP70 as endogenous stimulus of the Toll/interleukin-1 receptor signal pathway. J. Biol. Chem. 2002, 277, 15107-15112.

149. Basu, S.; Binder, R.J.; Suto, R.; Anderson, K.M.; Srivastava, P.K. Necrotic but not apoptotic cell death releases heat shock proteins, which deliver a partial maturation signal to dendritic cells and activate the NF-kappa B pathway. Int. Immunol. 2000, 12, 1539-1546.

150. Panjwani, N.N.; Popova, L.; Srivastava, P.K. Heat shock proteins gp96 and hsp70 activate the release of nitric oxide by APCs. J. Immunol. 2002, 168, 2997-3003.

151. Sanchez-Perez, L.; Kottke, T.; Daniels, G.A.; Diaz, R.M.; Thompson, J.; Pulido, J.; Melcher, A.; Vile, R.G. Killing of normal melanocytes, combined with heat shock protein 70 and CD40L expression, cures large established melanomas. J. Immunol. 2006, 177, 4168-4177.

152. Wang, Y.; Whittall, T.; McGowan, E.; Younson, J.; Kelly, C.; Bergmeier, L.A.; Singh, M.; Lehner, T. Identification of stimulating and inhibitory epitopes within the heat shock protein 70 molecule that modulate cytokine production and maturation of dendritic cells. J. Immunol. 2005, 174, 3306-3316.

153. Kuppner, M.C.; Gastpar, R.; Gelwer, S.; Nössner, E.; Ochmann, O.; Scharner, A.; Issels, R.D. The role of heat shock protein (hsp70) in dendritic cell maturation: Hsp70 induces the maturation of immature dendritic cells but reduces DC differentiation from monocyte precursors. Eur. J. Immunol. 2001, 31, 1602-1609.

154. Chen, T.; Guo, J.; Han, C.; Yang, M.; Cao, X. Heat shock protein 70, released from heat-stressed tumor cells, initiates antitumor immunity by inducing tumor cell chemokine production and activating dendritic cells via TLR4 pathway. J. Immunol. 2009, 182, 1449-1459. 
155. Stocki, P.; Dickinson, A.M. The immunosuppressive activity of heat shock protein 70 . Autoimmune Dis. 2012, 2012, 617213.

156. Van Eden, W.; Spiering, R.; Broere, F.; van der Zee, R. A case of mistaken identity: HSPs are no DAMPs but DAMPERs. Cell Stress Chaperones 2012, 17, 281-292.

157. Henderson, B.; Calderwood, S.K.; Coates, A.R.M.; Cohen, I.; van Eden, W.; Lehner, T.; Pockley, A.G. Caught with their PAMPs down? The extracellular signalling actions of molecular chaperones are not due to microbial contaminants. Cell Stress Chaperones 2010, 15, 123-141.

158. Tsan, M.-F.; Gao, B. Heat shock proteins and immune system. J. Leukoc. Biol. 2009, 85, 905-910.

159. Calderwood, S.K.; Murshid, A.; Gong, J. Heat shock proteins: Conditional mediators of inflammation in tumor immunity. Front. Immunol. 2012, 3, 75.

160. Multhoff, G.; Molls, M.; Radons, J. Chronic inflammation in cancer development. Front. Immunol. 2011, 2, 98.

161. Wachstein, J.; Tischer, S.; Figueiredo, C.; Limbourg, A.; Falk, C.; Immenschuh, S.; Blasczyk, R.; Eiz-Vesper, B. HSP70 enhances immunosuppressive function of CD4(+)CD25(+)FoxP3(+) T regulatory cells and cytotoxicity in CD4(+)CD25(-) T cells. PLoS One 2012, 7, e51747.

162. Chalmin, F.; Ladoire, S.; Mignot, G.; Vincent, J.; Bruchard, M.; Remy-Martin, J.-P.; Boireau, W.; Rouleau, A.; Simon, B.; Lanneau, D.; et al. Membrane-associated Hsp72 from tumor-derived exosomes mediates STAT3-dependent immunosuppressive function of mouse and human myeloid-derived suppressor cells. J. Clin. Invest. 2010, 120, 457-471.

163. Van Eden, W.; van der Zee, R.; Prakken, B. Heat-shock proteins induce T-cell regulation of chronic inflammation. Nat. Rev. Immunol. 2005, 5, 318-330.

164. Borges, T.J.; Wieten, L.; van Herwijnen, M.J.; Broere, F.; van der Zee, R.; Bonorino, C.; van Eden, W. The anti-inflammatory mechanisms of Hsp70. Front. Immunol. 2012, 3, 95.

165. Stocki, P.; Wang, X.N.; Dickinson, A.M. Inducible heat shock protein 70 reduces T cell responses and stimulatory capacity of monocyte-derived dendritic cells. J. Biol. Chem. 2012, 287, 12387-12394.

166. Evdonin, A.L.; Kropacheva, I.V.; Medvedeva, N.D. Extracellular Hsp70 stimulates multiple signaling pathways in A431 carcinoma cells. Biochem. Mosc. Suppl. Ser. A Membr. Cell Biol. 2009, 3, 291-297.

167. Ellerbroek, S.M.; Hudson, L.G.; Stack, M.S. Proteinase requirements of epidermal growth factor-induced ovarian cancer cell invasion. Int. J. Cancer 1998, 78, 331-337.

168. Jijon, H.B.; Buret, A.; Hirota, C.L.; Hollenberg, M.D.; Beck, P.L. The EGF receptor and HER2 participate in TNF- $\alpha$-dependent MAPK activation and IL-8 secretion in intestinal epithelial cells. Mediators Inflamm. 2012, 2012, 207398.

169. Wells, A. Tumor invasion: Role of growth factor-induced cell motility. Adv. Cancer Res. 2000, 78, 31-101.

170. Wu, F.-H.; Yuan, Y.; Li, D.; Liao, S.-J.; Yan, B.; Wei, J.-J.; Zhou, Y.-H.; Zhu, J.-H.; Zhang, G.-M.; Feng, Z.-H. Extracellular HSPA1A promotes the growth of hepatocarcinoma by augmenting tumor cell proliferation and apoptosis-resistance. Cancer Lett. 2012, 317, 157-164.

171. Gong, W.; Wang, Z.-Y.; Chen, G.-X.; Liu, Y.-Q.; Gu, X.-Y.; Liu, W.-W. Invasion potential of $\mathrm{H} 22$ hepatocarcinoma cells is increased by HMGB1-induced tumor NF- $\mathrm{BB}$ signaling via initiation of HSP70. Oncol. Rep. 2013, doi:10.3892/or.2013.2595. 
172. Ellerman, J.E.; Brown, C.K.; de Vera, M.; Zeh, H.J.; Billiar, T.; Rubartelli, A.; Lotze, M.T. Masquerader: High mobility group box-1 and cancer. Clin. Cancer Res. 2007, 13, 2836-2848.

173. Klink, M.; Nowak, M.; Kielbik, M.; Bednarska, K.; Blus, E.; Szpakowski, M.; Szyllo, K.; Sulowska, Z. The interaction of HspA1A with TLR2 and TLR4 in the response of neutrophils induced by ovarian cancer cells in vitro. Cell Stress Chaperones 2012, 17, 661-674.

174. Ushio-Fukai, M.; Alexander, R.W. Reactive oxygen species as mediators of angiogenesis signaling: Role of NAD(P)H oxidase. Mol. Cell. Biochem. 2004, 264, 85-97.

175. De Larco, J.E.; Wuertz, B.R.K.; Furcht, L.T. The potential role of neutrophils in promoting the metastatic phenotype of tumors releasing interleukin-8. Clin. Cancer Res. 2004, 10, 4895-4900.

176. Wheeler, D.S.; Chase, M.A.; Senft, A.P.; Poynter, S.E.; Wong, H.R.; Page, K. Extracellular Hsp72, an endogenous DAMP, is released by virally infected airway epithelial cells and activates neutrophils via Toll-like receptor (TLR)-4. Respir. Res. 2009, 10, 31.

177. Becker, T.; Hartl, F.-U.; Wieland, F. CD40, an extracellular receptor for binding and uptake of Hsp70-peptide complexes. J. Cell Biol. 2002, 158, 1277-1285.

178. Wang, Y.; Kelly, C.G.; Karttunen, J.T.; Whittall, T.; Lehner, P.J.; Duncan, L.; MacAry, P.; Younson, J.S.; Singh, M.; Oehlmann, W.; et al. CD40 is a cellular receptor mediating mycobacterial heat shock protein 70 stimulation of CC-chemokines. Immunity 2001, 15, 971-983.

179. Van Kooten, C.; Banchereau, J. CD40-CD40 ligand. J. Leukoc. Biol. 2000, 67, 2-17.

180. Futagami, S.; Hiratsuka, T.; Shindo, T.; Hamamoto, T.; Horie, A.; Ueki, N.; Kusunoki, M.; Gudis, K.; Miyake, K.; Tsukui, T.; et al. Extracellular HSP70 blocks CD40L-induced apoptosis and tubular formation in endothelial cells. J. Gastroenterol. Hepatol. 2008, 23, S222-S228.

181. Zhan, R.; Leng, X.; Liu, X.; Wang, X.; Gong, J.; Yan, L.; Wang, L.; Wang, Y.; Wang, X.; Qian, L.-J. Heat shock protein 70 is secreted from endothelial cells by a non-classical pathway involving exosomes. Biochem. Biophys. Res. Commun. 2009, 387, 229-233.

182. Peinado, H.; Alečković, M.; Lavotshkin, S.; Matei, I.; Costa-Silva, B.; Moreno-Bueno, G.; Hergueta-Redondo, M.; Williams, C.; García-Santos, G.; Ghajar, C.; et al. Melanoma exosomes educate bone marrow progenitor cells toward a pro-metastatic phenotype through MET. Nat. Med. 2012, 18, 883-891.

183. Goloudina, A.R.; Demidov, O.N.; Garrido, C. Inhibition of HSP70: A challenging anti-cancer strategy. Cancer Lett. 2012, 325, 117-124.

184. Murshid, A.; Gong, J.; Stevenson, M.A.; Calderwood, S.K. Heat shock proteins and cancer vaccines: Developments in the past decade and chaperoning in the decade to come. Expert Rev. Vaccines 2011, 10, 1553-1568.

185. Ciocca, D.R.; Cayado-Gutierrez, N.; Maccioni, M.; Cuello-Carrion, F.D. Heat shock proteins (HSPs) based anti-cancer vaccines. Curr. Mol. Med. 2012, 12, 1183-1197.

186. Garg, M.; Kanojia, D.; Seth, A.; Kumar, R.; Gupta, A.; Surolia, A.; Suri, A. Heat-shock protein 70-2 (HSP70-2) expression in bladder urothelial carcinoma is associated with tumour progression and promotes migration and invasion. Eur. J. Cancer 2010, 46, 207-215.

187. Du, X.L.; Jiang, T.; Wen, Z.Q.; Gao, R.; Cui, M.; Wang, F. Silencing of heat shock protein 70 expression enhances radiotherapy efficacy and inhibits cell invasion in endometrial cancer cell line. Croat. Med. J. 2009, 50, 143-150. 
188. Weber, G.F. Why does cancer therapy lack effective anti-metastasis drugs? Cancer Lett. 2013, $328,207-211$.

189. Weng, D.; Penzner, J.H.; Song, B.; Koido, S.; Calderwood, S.K.; Gong, J. Metastasis is an early event in mouse mammary carcinomas and is associated with cells bearing stem cell markers. Breast Cancer Res. 2012, 14, R18.

190. Botzler, C.; Issels, R.; Multhoff, G. Heat-shock protein 72 cell-surface expression on human lung carcinoma cells in associated with an increased sensitivity to lysis mediated by adherent natural killer cells. Cancer Immunol. Immunother. 1996, 43, 226-230.

191. Stangl, S.; Wortmann, A.; Guertler, U.; Multhoff, G. Control of metastasized pancreatic carcinomas in SCID/beige mice with human IL-2/TKD-activated NK cells. J. Immunol. 2006, 176, 6270-6276.

192. Botzler, C.; Schmidt, J.; Luz, A.; Jennen, L.; Issels, R.; Multhoff, G. Differential Hsp70 plasma-membrane expression on primary human tumors and metastases in mice with severe combined immunodeficiency. Int. J. Cancer 1998, 77, 942-948.

193. Multhoff, G.; Pfister, K.; Botzler, C.; Jordan, A.; Scholz, R.; Schmetzer, H.; Burgstahler, R.; Hiddemann, W. Adoptive transfer of human natural killer cells in mice with severe combined immunodeficiency inhibits growth of Hsp70-expressing tumors. Int. J. Cancer 2000, 88, 791-797.

194. Moser, C.; Schmidbauer, C.; Gürtler, U.; Gross, C.; Gehrmann, M.; Thonigs, G.; Pfister, K.; Multhoff, G. Inhibition of tumor growth in mice with severe combined immunodeficiency is mediated by heat shock protein 70 (Hsp70)-peptide-activated, CD94 positive natural killer cells. Cell Stress Chaperones 2002, 7, 365-373.

195. Krause, S.W.; Gastpar, R.; Andreesen, R.; Gross, C.; Ullrich, H.; Thonigs, G.; Pfister, K.; Multhoff, G. Treatment of colon and lung cancer patients with ex vivo heat shock protein 70-peptide-activated, autologous natural killer cells: A clinical phase i trial. Clin. Cancer Res. 2004, 10, 3699-3707.

196. Milani, V.; Stangl, S.; Issels, R.; Gehrmann, M.; Wagner, B.; Hube, K.; Mayr, D.; Hiddemann, W.; Molls, M.; Multhoff, G. Anti-tumor activity of patient-derived NK cells after cell-based immunotherapy-A case report. J. Transl. Med. 2009, 7, 50.

197. Gehrmann, M.; Stangl, S.; Kirschner, A.; Foulds, G.A.; Sievert, W.; Doss, B.T.; Walch, A.; Pockley, A.G.; Multhoff, G. Immunotherapeutic targeting of membrane Hsp70-expressing tumors using recombinant human granzyme B. PLoS One 2012, 7, e41341.

(C) 2013 by the authors; licensee MDPI, Basel, Switzerland. This article is an open access article distributed under the terms and conditions of the Creative Commons Attribution license (http://creativecommons.org/licenses/by/3.0/). 